\title{
Inorganic and organic nitrogen uptake by nine dominant subtropical tree species
}

\author{
Changcheng $\mathbf{L i} i^{(1-2)}$, Qianru $\mathbf{L i}{ }^{(1-2)}$, \\ $\mathrm{Na} Q \mathrm{Qiao}^{(3)}$, Xingliang $\mathrm{Xu}{ }^{(1)}$, \\ Qingkang $\mathbf{L i}^{\left({ }^{(1)}\right.}$, Huimin Wang ${ }^{(1)}$
}

\begin{abstract}
We explored inorganic and organic $\mathrm{N}$ uptake patterns by dominant tree species in a subtropical plantation of southern China to improve understanding of nitrogen $(\mathrm{N})$ cycling in these forests. We labeled intact roots by brief ${ }^{15} \mathrm{~N}$ exposures in field hydroponic experiments. Nine dominant tree species were examined to compare the effects of functional plant group (conifers versus broadleaves), mycorrhizal types, and forest successional stages on $\mathrm{N}$ uptake. All investigated species took up glycine at lower rates than other $\mathrm{N}$ forms, with mean values of $2.55 \pm 0.36 \mu \mathrm{g} \mathrm{N} \mathrm{g}{ }^{-1} \mathrm{~d}$.w. root $\mathrm{h}^{-1}$. Nitrate uptake rates for all species (average $5.81 \pm 0.35 \mu \mathrm{g} \mathrm{N} \mathrm{g}{ }^{-1} \mathrm{~d} . \mathrm{w}$. root $\mathrm{h}^{-1}$ ) were significantly lower than ammonium $\left(36.86 \pm 5.17 \mu g \mathrm{~N} \mathrm{~g}^{-1}\right.$ d.w. root $\left.h^{-1}\right)$. All investigated species absorbed ammonium for more than $80 \%$ of total $\mathrm{N}$ uptake. Nitrate acquisition by these species was about $14 \%$ of total $N$ uptake, with only $6 \%$ for glycine. Conifers showed significantly higher uptake rates of glycine, but lower uptake of nitrate than broadleaves. Arbuscular mycorrhizal (AM) and ectomycorrhizal (ECM) tree species showed significant difference in nitrate uptake, with higher rates by $A M$ tree species. Tree species at late-successional forest stages showed higher uptake rates of nitrate than those in earlier successional stages. Our findings indicate that ammonium is the dominant $\mathrm{N}$ source and glycine is a minor $\mathrm{N}$ source throughout forest succession.
\end{abstract}

Keywords: Plant Functional Group, AM Fungi, ECM Fungi, N Uptake, Subtropical Tree Species, Succession tude regions are often dominated by tundra (Nordin et al. 2004), boreal (Finzi \& Berthrong 2005, Leduc \& Rothstein 2010), alpine (Xu et al. 2004) and temperate (Bardgett et al. 2003, Warren 2006, Harrison et al. 2007, Warren \& Adams 2007, Warren 2009a, 2009b) forests. Many studies of inorganic and organic $\mathrm{N}$ uptake have been done in these ecosystems.

Recent studies in subtropical and tropical forests investigated $\mathrm{N}$ acquisition by tree species (Schmidt \& Stewart 1997, Schmidt et al. 2003, Andersen \& Turner 2013), showing dominant tree species in these regions absorb organic $\mathrm{N}$ as intact amino acids. Few such studies have been conducted in subtropical forests. Subtropical
(1) Key Laboratory of Ecosystem Network Observation and Modeling, Institute of Geographic Sciences and Natural Resources Research, Chinese Academy of Sciences, Beijing 100101 (China); (2) University of Chinese Academy of Sciences, Beijing 100039 (China); (3) Key Laboratory of Tropical Forest Ecology, Xishuangbanna Tropical Botanical Garden, Chinese Academy of Sciences, No. 88 Xuefu Road, Kunming 650223, Yunnan (P.R. China)

@ Xingliang Xu (xuxingl@hotmail.com)

Received: Nov 14, 2014 - Accepted: Oct 07, 2015

Citation: Li C, Li Q, Qiao N, Xu X, Li Q, Wang H (2015). Inorganic and organic nitrogen uptake by nine dominant subtropical tree species. iForest 9: 253-258. - doi: 10.3832/ifor1502-008 [online 2015-12-02]

Communicated by: Giustino Tonon forests are widely distributed in southern China and occupy about $2.4 \times 10^{6} \mathrm{~km}^{2}$. In the past decades, a large area of subtropical forests has been modified by anthropogenic activities. Many plantations have been established in these regions to support local economic development. Low $\mathrm{N}$ availability in plantations can limit tree growth and wood production. Therefore, to clarify the $\mathrm{N}$ uptake pattern by dominant tree species will be beneficial to the management of these plantations through improved supply of $\mathrm{N}$ forms. Additionally, the importance of distinguishing plant $\mathrm{N}$ sources has increased for better understanding the ecological consequences of $\mathrm{N}$ uptake by plants (Britto \& Kronzucker 2013, Bloom 2015).

To investigate organic and inorganic $\mathrm{N}$ uptake by subtropical trees, we selected a subtropical plantation at the research station of Qianyanzhou. Nine dominant tree species (three conifers and six broadleaves, i.e., Pinus massoniana, Pinus elliottii, Schima superba, Magnolia officinalis, Cyclobalanopsis glauca, Machilus velutina, Cunninghamia lanceolata, Michelia maudiae and Cinnamomum camphora) were selected based on their successional stages and mycorrhizal types. Numerous studies have suggested that plant functional group and mycorrhizal type can affect root nutrientuptake functions (Marschner \& Dell 1994, Hooper \& Vitousek 1997, Bonfante \& Anca 2009, Li et al. 2011, Miransari 2011). There- 
Tab. 1 - The nine dominant tree species analyzed in subtropical plantations at the Qianyanzhou research station. ECM refers to ectomycorrhiza while AM indicates arbuscular mycorrhiza.

\begin{tabular}{|c|c|c|c|c|c|}
\hline Tree species & ID & Family & $\begin{array}{l}\text { Functional } \\
\text { group }\end{array}$ & $\begin{array}{l}\text { Mycorrhizal } \\
\text { type }\end{array}$ & $\begin{array}{l}\text { Successional } \\
\text { stages }\end{array}$ \\
\hline Pinus massoniana & PMA & Pinaceae & Coniferous & ECM & Early \\
\hline Pinus elliottii & PEL & Pinaceae & Coniferous & ECM & Early \\
\hline Schima superba & SSU & Theaceae & Broad-leaved & $A M$ & Intermediate \\
\hline Magnolia officinalis & MOF & Magnoliaceae & Broad-leaved & $A M$ & Late \\
\hline Cyclobalanopsis glauca & CGL & Fagaceae & Broad-leaved & ECM & Late \\
\hline Machilus velutina & MVE & Lauraceae & Broad-leaved & $A M$ & Late \\
\hline $\begin{array}{l}\text { Cunninghamia } \\
\text { lanceolata }\end{array}$ & CLA & Taxodiaceae & Coniferous & ECM & Late \\
\hline Michelia maudiae & MMA & Magnoliaceae & Broad-leaved & $A M$ & Late \\
\hline $\begin{array}{l}\text { Cinnamomum } \\
\text { camphora }\end{array}$ & $\mathrm{CCA}$ & Lauraceae & Broad-leaved & $\mathrm{AM}$ & Late \\
\hline
\end{tabular}

fore, we hypothesized that broadleaves preferentially absorb nitrate, whereas more ammonium and glycine is adsorbed by conifers. Additionally, we hypothesized that ectomycorrhizal (ECM) tree species have stronger capacity to take up organic and inorganic $\mathrm{N}$ than arbuscular mycorrhizal (AM) tree species. Generally, nitrate dominates early successional soils, while ammonium becomes the major $\mathrm{N}$ form at later stages (Britto \& Kronzucker 2013). We hypothesized that pioneer tree species preferentially utilize nitrate, while tree species in later successional stages utilize more ammonium and dissolved amino acids. To test these hypotheses, we conducted a short-term ${ }^{15} \mathrm{~N}$ labeling experiment in subtropical plantations.

\section{Materials and methods}

Study site

This study was conducted in a plantation at the Qianyanzhou Ecological Experimental Station $\left(26^{\circ} 44^{\prime} \mathrm{N}, 115^{\circ} 04^{\prime} \mathrm{E}, 102 \mathrm{~m}\right.$ a.s.l.), Jiangxi Province of southern China. The site is characterized by a typical subtropical climate. The mean annual air temperature was $17.9{ }^{\circ} \mathrm{C}$ (Wen et al. 2006), while mean annual precipitation was 1542 $\mathrm{mm}$, with a dry period from July to August (Wang et al. 2011). The region is dominated by subtropical evergreen broad-leaved fo- rests. Before 1983, the native forests were nearly completely cleared, leading to serious soil erosion and land degradation. Subsequently, several large projects of reforestation and sustainable land use projects were initiated to improve ecosystem structure and function as well as local economic development. With the establishment of these plantations, secondary forests have also developed. Soils are red soils, classified as aliudic cambosols and derived from sandstone, sandy conglomerate, mudstone and alluvium (SITCAS 1989). Soils have total $N$ concentrations less than $0.1 \%$ (Ma et al. 2014).

\section{Field hydroponic experimental design}

In these plantations, nine dominant tree species (Pinus massoniana Lamb., Pinus elliottii Engelm., Schima superba Gard., Magnolia officinalis Rehd. et Wils., Cyclobalanopsis glauca (Thunb.) Oerst., Machilus velutina Champ. ex Benth., Cunninghamia lanceolata (Lamb.) Hook, Michelia maudiae Dunn. and Cinnamomum camphora (L.) Presl.) were selected to examine their in situ $\mathrm{N}$ uptake by roots. They were divided into different functional groups: conifers versus broadleaves, ectomycorrhizal (ECM) versus arbuscular mycorrhizal (AM) trees or early versus late successional species (Tab. 1). The general characteristics of the 9 tree species were described in Tab. 2.
To examine their $\mathrm{N}$ uptake, a mixture of ammonium, nitrate and glycine was used. Glycine was used as an organic $\mathrm{N}$ source, because it is a common low-molecularweight amino acid in soils (Lipson \& Näsholm 2001). Three labeling solutions and one controlled solution were used. Each solution contained equal parts of ammonium, nitrate and glycine $\left(33 \mu \mathrm{mol} \mathrm{N} \mathrm{L}{ }^{-1}\right.$ for each $\mathrm{N}$ form) to provide a "choice" of different $\mathrm{N}$ sources. Each labeling solution only contained one of the three tracers: 10 atom\% $\mathrm{K}^{15} \mathrm{NO}_{3}, 10$ atom\% $\left({ }^{15} \mathrm{NH}_{4}\right)_{2} \mathrm{SO}_{4}$ and 99 atom\% ${ }^{15} \mathrm{~N}$-glycine, while the other two were not labeled with ${ }^{15} \mathrm{~N}$. This allowed to discern $\mathrm{N}$ uptake patterns of the chemical forms of $\mathrm{N}$ among the species. In addition, a solution containing all three $\mathrm{N}$ chemical forms without labelled ${ }^{15} \mathrm{~N}$ tracer was used as control to examine natural variation in $\delta^{15} \mathrm{~N}$ values among the species. In addition to $\mathrm{N}$, uptake solutions contained $10 \mathrm{mg} \mathrm{L}^{-1}$ of ampicillin to minimize microbial activity and avoid the decomposition of the amino acid and $0.2 \mathrm{mM} \mathrm{CaCl}$, to maintain the function of roots (Warren \& Adams 2007).

The labelling was performed at 9:00 am in July 2013. Soil temperature was about 26 ${ }^{\circ} \mathrm{C}$. Five trees of similar size were randomly selected in each tree species. Four pairs of fine roots with diameter less than $2 \mathrm{~mm}$ (weight ranged from 0.05 to $0.20 \mathrm{~g}$ for a fine root; length was about $15 \mathrm{~cm}$ for every root) were dug out diagonally along the stem base for each tree. Each treatment had 10 replicates. After rinsing with water, they were immersed into the labeling solution in $15 \mathrm{ml}$ centrifuge tubes, individually. After 2 hours, they were excised, washed with $50 \mathrm{mM} \mathrm{KCl}$, and then rinsed with $\mathrm{H}_{2} \mathrm{O}$. All root materials were dried at $70^{\circ} \mathrm{C}$ for 48 $\mathrm{h}$ to measure dry mass. Dried roots were ground into fine power and weighted into tin capsules for measurements of $\mathrm{N}$ content and ${ }^{15} \mathrm{~N} /{ }^{14} \mathrm{~N}$ ratios by continuous-flow isotope ratio mass spectrometry coupled with an elemental analyzer (EA 1110 - CE Instruments, Milan, Italy) and a ConFlo II device connected to IRMS (Finnigan MAT 253, Bremen, Germany).

\section{Calculations and statistics}

${ }^{15} \mathrm{~N}$ calculations were based on ${ }^{15} \mathrm{~N}$ atom

Tab. 2 - General characteristics of the nine dominant tree species analyzed in the Qianyanzhou forest ecosystem. Values are presented as mean $\pm \mathrm{SE}$ of five replicates.

\begin{tabular}{lccrrr}
\hline Tree species & $\begin{array}{c}\text { Mean } \\
\text { tree height }(\mathbf{m})\end{array}$ & $\begin{array}{c}\text { Mean diameter } \\
\text { at breast height }(\mathbf{c m})\end{array}$ & $\begin{array}{c}\text { Water } \\
\text { content }(\%)\end{array}$ & $\begin{array}{c}\mathrm{NO}_{3}{ }^{-}-\mathbf{N}^{-1} \\
\left(\mathbf{m g ~ k g}^{-1}\right)\end{array}$ & $\begin{array}{c}\mathrm{NH}_{4}{ }^{+}-\mathbf{N} \\
\left(\mathbf{m g ~ k g}^{-1}\right)\end{array}$ \\
\hline Pinus massoniana & $11.36 \pm 0.80$ & $21.06 \pm 1.86$ & $11.87 \pm 1.34$ & $0.89 \pm 0.28$ & $4.87 \pm 0.44$ \\
\hline Pinus elliottii & $15.48 \pm 0.21$ & $26.52 \pm 0.84$ & $9.86 \pm 0.47$ & $0.41 \pm 0.07$ & $6.41 \pm 1.30$ \\
\hline Schima superba & $19.90 \pm 1.22$ & $19.54 \pm 1.58$ & $14.12 \pm 1.96$ & $1.92 \pm 0.12$ & $14.60 \pm 3.37$ \\
\hline Magnolia officinalis & $11.20 \pm 0.70$ & $16.54 \pm 0.92$ & $19.47 \pm 0.06$ & $0.75 \pm 0.06$ & $18.93 \pm 1.98$ \\
\hline Cyclobalanopsis glauca & $10.00 \pm 0.57$ & $15.00 \pm 1.23$ & $12.60 \pm 2.62$ & $1.97 \pm 0.56$ & $21.74 \pm 6.40$ \\
\hline Machilus velutina & $5.30 \pm 0.14$ & $4.89 \pm 0.15$ & $4.17 \pm 1.20$ & $1.29 \pm 0.24$ & $6.61 \pm 1.65$ \\
\hline Cunninghamia lanceolata & $20.56 \pm 0.56$ & $25.82 \pm 0.85$ & $13.24 \pm 0.95$ & $2.48 \pm 0.43$ & $6.94 \pm 1.20$ \\
\hline Michelia maudiae & $8.92 \pm 0.41$ & $12.00 \pm 1.03$ & $9.18 \pm 0.26$ & $1.09 \pm 0.11$ & $15.40 \pm 1.11$ \\
\hline Cinnamomum camphora & $10.56 \pm 0.65$ & $19.16 \pm 1.66$ & $15.62 \pm 0.88$ & $1.24 \pm 0.64$ & $16.10 \pm 3.21$ \\
\hline
\end{tabular}


percent excess (APE), calculated as the difference between ${ }^{15} \mathrm{~N}$ treated and control plants. $\mathrm{N}$ uptake rates $\left(\mu \mathrm{g} \mathrm{N} \mathrm{g}^{-1}\right.$ d.w. root $\mathrm{h}^{-1}$ ) were calculated multiplying APE by dry root biomass and its $\mathrm{N}$ content and divided by dry root biomass, APE of labeled $\mathrm{N}$ and the labeling hours. The contribution of each $\mathrm{N}$ form was calculated by dividing its uptake rate by the total uptake of three $\mathrm{N}$ forms.

Differences in uptake rates for three $\mathrm{N}$ forms among tree species were analyzed using a one-way analysis of variance (ANOVA). Two-way ANOVA was used to examine the effects of $\mathrm{N}$ forms and tree species on $\mathrm{N}$ uptake rates. Statistical calculations were performed with the statistical software package SPSS ${ }^{\circledast}$ ver. 18 (SPSS Inc., Chicago, IL, USA). Least significant difference (LSD) was used to compare the mean values as post-hoc test. All differences were tested at the $\mathrm{P}<0.05$ level. Standard errors (SE) of means are presented in the figures as a variability parameter.

\section{Results}

Tree species and $\mathrm{N}$ forms as well as their interactions significantly affected $\mathrm{N}$ uptake by roots (Tab. 2). All nine tree species took up glycine at lowest rate as compared to other $\mathrm{N}$ forms, with mean values about $2.55 \pm 0.36 \mu \mathrm{g} \mathrm{N} \mathrm{g}{ }^{-1}$ d.w. root $h^{-1}$ (Fig. 1). Among tree species, $P$. elliottii showed the highest uptake rate for glycine, while $C$. glauca took up glycine at lowest rate, with significant difference in uptake rates between some tree species (Fig. 1). Uptake rates of nitrate for all nine tree species ranged from $4.30 \pm 0.50$ to $7.55 \pm 0.33 \mu \mathrm{g} \mathrm{N}$ $\mathrm{g}^{-1} \mathrm{~d}$.w. root $\mathrm{h}^{-1}$, higher than glycine uptake (ranging from $1.92 \pm 0.14$ to $7.01 \pm 1.47 \mu \mathrm{g} \mathrm{N}$ $\mathrm{g}^{-1}$ d.w. root $\mathrm{h}^{-1}$ ) but lower than ammonium uptake (varying from $22.10 \pm 1.60$ to $56.56 \pm$ $5.90 \mu \mathrm{g} \mathrm{N} \mathrm{g-1}$ d.w. root $\left.\mathrm{h}^{-1}\right)$. Pinus elliottii had the highest uptake rate for ammonium, while C. glauca showed the lowest uptake rates for ammonium (Fig. 1).

All species showed a preferential uptake for ammonium which accounted for more than $80 \%$ of total uptake for three $\mathrm{N}$ forms (Fig. 2). The contribution of nitrate uptake to all nine tree species was estimated to be about $15 \%$ of total uptake of three $\mathrm{N}$ forms, with the lowest value for $P$. elliottii (Fig. 2). The contribution of glycine uptake to $P$. massoniana and $P$. elliottii was similar to that of nitrate uptake. Thus, the overall pattern of uptake from the three $\mathrm{N}$ sources was: glycine < nitrate < ammonium (Fig. 2).

Conifers showed significantly higher uptake rates for glycine but lower uptake rate for nitrate than broadleaves (Tab. 3, Fig. 3). $A M$ and ECM tree species showed significant difference in nitrate uptake, with higher rates for AM tree species (Fig. 4). Tree species from early successional stage showed stronger capacity to take up ammonium and glycine than those from later successional stage, with significant differences in glycine uptake between those groups.

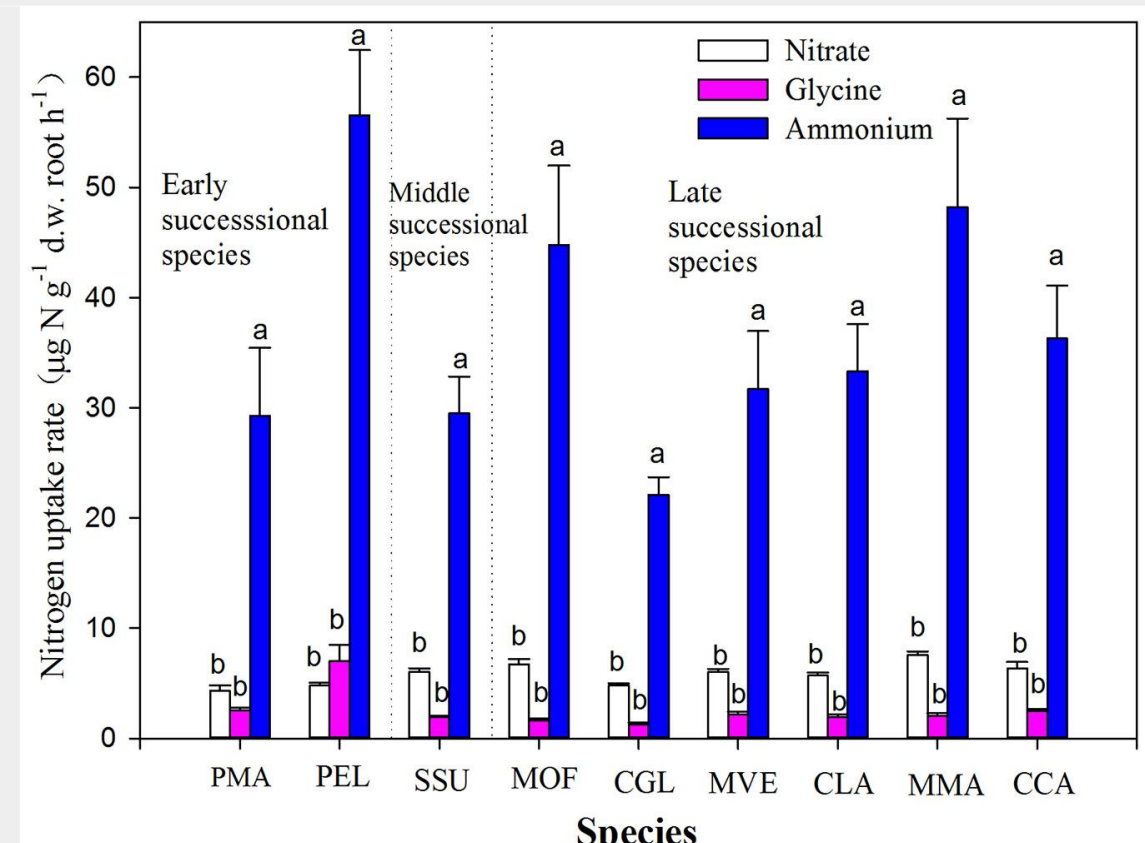

Fig. 1 - Uptake rates of glycine, ammonium and nitrate by nine dominant tree species in a subtropical plantation. Values are presented as mean \pm SE of ten replicates. Different letters above the bars indicates significant difference in nitrogen uptake between nitrogen forms for each species $(P<0.05)$. Labels of tree species are the same as in Tab. 1.

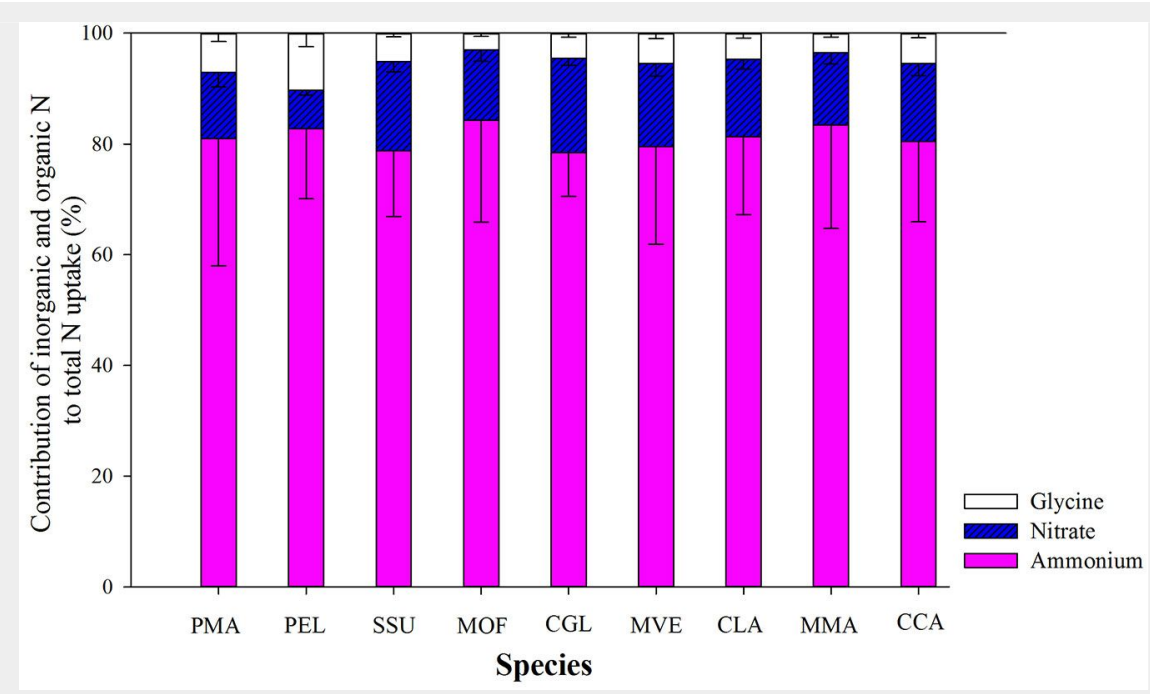

Fig. 2 - The proportional contribution of nitrate, glycine and ammonium to total nitrogen uptake by trees in a subtropical plantation. Values are presented as mean \pm SE of ten replicates. Labels of tree species are the same as in Tab. 1.

Tab. 3 - Two-way analysis of variance (ANOVA) testing the effects of tree species and $\mathrm{N}$ forms on $\mathrm{N}$ uptake by plants in a subtropical plantation. $\mathrm{P}$ values for significant effects and interactions are reported.

\begin{tabular}{lrrrc}
\hline Factors & $\begin{array}{c}\text { Mean } \\
\text { Square }\end{array}$ & df & F & P values \\
\hline Tree species & 6.927 & 8 & 5.930 & $<0.001$ \\
\hline $\mathrm{N}$ forms & 217.064 & 2 & 185.829 & $<0.001$ \\
\hline Tree species $\times \mathrm{N}$ forms & 3.848 & 16 & 3.295 & $<0.001$ \\
\hline Error & 1.168 & 243 & - & - \\
\hline
\end{tabular}




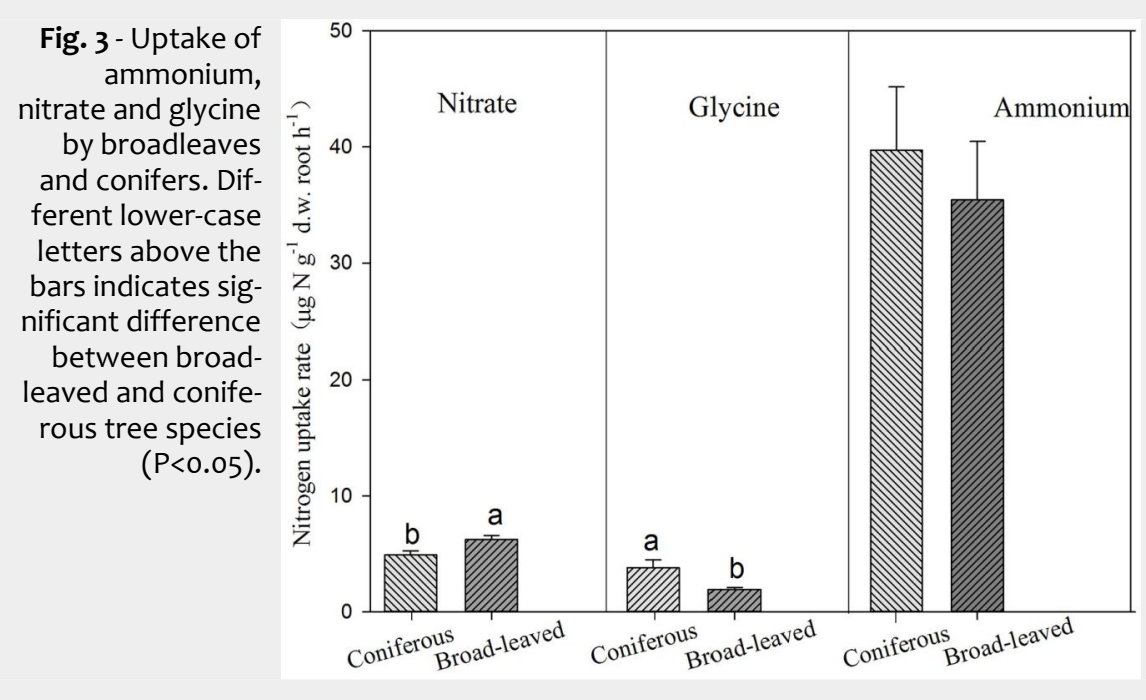

Fig. 4 - Uptake of
ammonium,
nitrate and glycine
by ectomycorrhizal
(ECM) and arbus-
cular mycorrhizal
(AM) trees. Diffe-
rent lower-case
letters above the
bars indicates sig-
nificant difference
between ECM and
AM tree species
$(P<0.05)$.

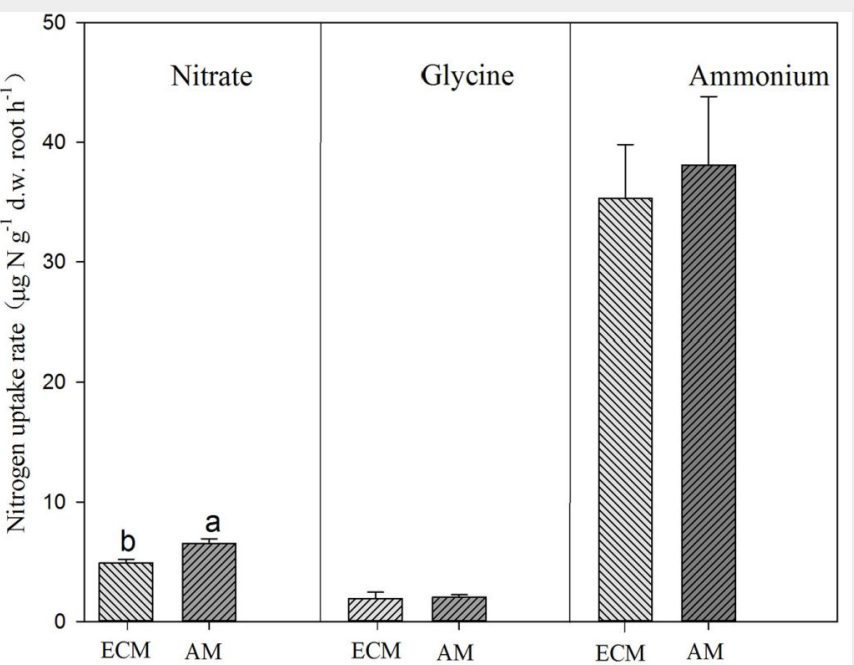

Fig. 5 - Uptake of ammonium, nitrate and glycine by trees in early and late successional stages. Different

lower-case letters above the bars indicates significant difference

between tree species in early and late successional stages $(P<0.05)$

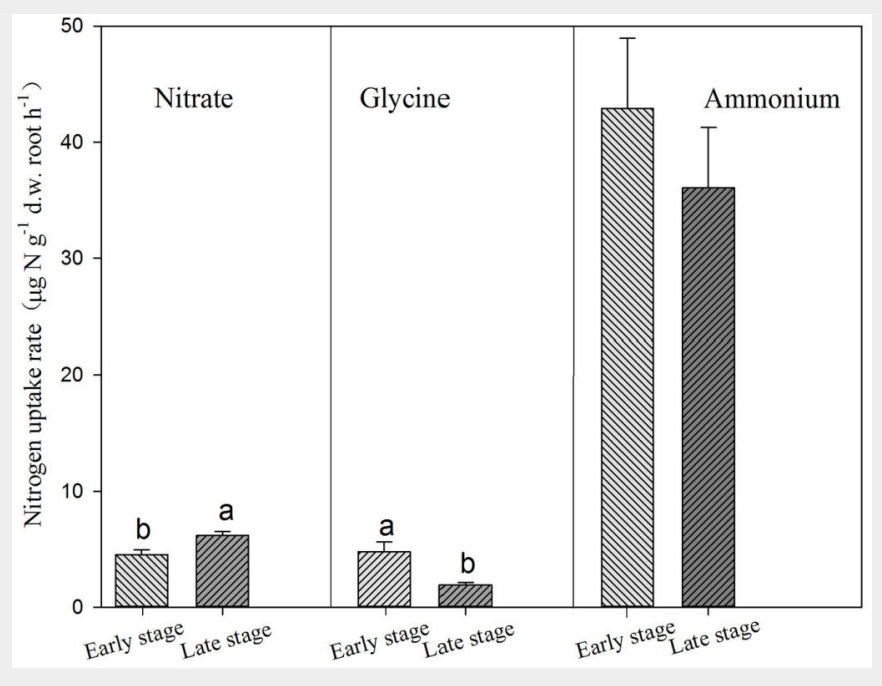

By comparison, tree species at late successional stage showed higher uptake rates for nitrate than early successional species (Fig. 5).

\section{Discussion}

We investigated inorganic and organic $\mathrm{N}$ acquisition patterns by nine dominant tree species in a subtropical plantation using short-term ${ }^{15} \mathrm{~N}$ labeling. These dominant trees showed similar uptake rates of nitrate to those trees in subtropical rainforests, but 3 times uptake of glycine and ammonium (Schmidt \& Stewart 1997). Our estimated uptake rates of all three $\mathrm{N}$ forms were similar to those of temperate and sub-alpine trees (Warren 2009a, 2009b). Our results demonstrated that investigated dominant subtropical tree species preferentially take up ammonium, contributing about $80 \%$ of total $\mathrm{N}$ uptake by these dominant trees. This may relate to ammonium dominance of this soil solution (Tab. 2 Kou et al. 2015). Additionally, this study used hydroponic solution, in which microbial competition and adsorption of $\mathrm{NH}_{4}^{+}$ ions by soil minerals are excluded. $\mathrm{NH}_{4}{ }^{+}$diffusion is relatively faster, with higher concentrations, in the uptake solution than in soils. These factors could increase ammonium uptake by roots of these subtropical trees.

Nonetheless, such $\mathrm{N}$ uptake patterns here provide a basis for understanding ecological consequences of $\mathrm{N}$ uptake by worldwide subtropical trees. In the rhizosphere, microorganisms strongly compete for $\mathrm{N}$ with roots (Kuzyakov \& Xu 2013). The strong dependence on ammonium of all investigated trees indicates that they could strongly compete for ammonium in soil solution. However, these dominant trees grow together very well. This suggests that rapid mineralization may provide enough ammonium for these trees; otherwise the other $\mathrm{N}$ sources may be not accounted in this study. Additionally, subtropical soils are generally characterized by low $\mathrm{pH}$. Numerous factors such as acidic atmospheric deposition and $\mathrm{N}$ transformations have been suggested to cause soil acidification (Van Breemen et al. 1983). Ammonium uptake by roots also has potential to decrease $\mathrm{pH}$ in the rhizosphere (Nye 1981). This indicates that the preference for ammonium by these dominant trees could lead to the substantial decrease in soil $\mathrm{pH}$ during forest succession. However, this still needs further investigations for understanding the ecological consequences (e.g., soil acidification as well as tree coexistence) of the preference for ammonium by worldwide subtropical trees.

Both broadleaves and conifers preferentially take up ammonium and glycine (Fig. 3), but broadleaves show higher nitrate uptake than conifers. Therefore, our first hypothesis is partly supported. This indicates substantial difference in root physiology between broadleaves and conifers, but underlying mechanisms should be investigated for a better understanding of $\mathrm{N}$ uptake by roots.

Numerous studies have suggested that mycorrhiza can enhance $\mathrm{N}$ uptake by roots (Alexander 2007, Smith \& Read 2008). Although many studies have explored how ECM or AM affect $\mathrm{N}$ uptake by roots (George et al. 1995, Read \& Perez-Moreno 2003, Finlay 2005, Hodge \& Fitter 2010, Miransari 2011, Veresoglou et al. 2012), few studies have been conducted to compare $\mathrm{N}$ uptake by mycorrhiza. Here we observed that ECM tree species did not show stronger capacity to take up ammonium and glycine than AM tree species, while AM tree species acquire nitrate faster than ECM tree species (Fig. 4). These results are contrary to our second hypothesis. These species are known for mycorrhizal infection patterns, but we did not measure infection in this 
study. Therefore, our results represent a conservative speculation on effects of ECM or AM on $\mathrm{N}$ uptake by trees. Nitrogen-labeling of trees with demonstrated $A M$ or ECM infections should be conducted.

Although it has been suggested that pioneer species acquire more nitrate while later successional species take up more ammonium (Britto \& Kronzucker 2013), we did not observe this pattern in this study. Contrary to our hypothesis, tree species in both early and late stages utilize more ammonium and glycine (Fig. 5). However, late tree species showed higher uptake of nitrate and lower uptake of glycine than pioneer tree species. A possible explanation is that these plantations are part of secondary succession, developing on preexisting soils, where ammonium is the dominant $\mathrm{N}$ form (Tab. 2 - Kou et al. 2015).

In summary, ammonium is the major $\mathrm{N}$ source for these investigated nine subtropical tree species and nitrate is also important for these trees except for Pinus species. Glycine was selected as organic $\mathrm{N}$ in this experiment and was not preferred by any species, but subtropical soils contain other dissolved amino acids which may be significant $\mathrm{N}$ sources for trees. Future investigation should consider other amino acids for a better understanding of $\mathrm{N}$ cycling in subtropical forests. As these results were measured using field hydroponic experiment, microenvironments around roots (e.g., microbial competition and interactions among roots) were changed. This could change $\mathrm{N}$-uptake patterns. To improve knowledge of $\mathrm{N}$ uptake by tree species, in situ $\mathrm{N}$ uptake should be investigated including mycorrhizal status, microbial competition, soil $\mathrm{N}$ forms availability, seasons, and developmental stages of trees.

\section{Acknowledgements}

This study was supported by National Basic Research Program of China (2012CB 416903) and the National Natural Science Foundation of China (31130009 and 4107 1209) the Knowledge Innovation Foundation Program for Outstanding Young Scholar of the Chinese Academy of Sciences (KZCX2-YW-QN302).

\section{References}

Andersen KM, Turner BL (2013). Preferences or plasticity in nitrogen acquisition by understorey palms in a tropical montane forest. Journal of Ecology 101: 819-825. - doi: 10.1111/1365-2745.12 070

Alexander I (2007). A knight of symbiosis. New Phytologist 176: 499-510. - doi: 10.1111/j.14698137.2007.02259.x

Bardgett RD, Steeter TC, Bol R (2003). Soil microorganisms compete effectively with plants for organic-nitrogen inputs to temperate grasslands. Ecology 84: 1277-1387. - doi: 10.1890/00129658(2003)084[1277:SMCEWP]2.0.CO;2

Bloom AJ (2015). The increasing importance of distinguishing among plant nitrogen sources. Current Opinion in Plant Biology 25: 10-16. - doi: 10.1016/j.pbi.2015.03.002

Bonfante P, Anca IA (2009). Plants, mycorrhizal fungi, and bacteria: a network of interactions. Annual Reviews of Microbiology 63: 363-383. doi: 10.1146/annurev.micro.091208.073504

Britto DT, Kronzucker HJ (2013). Ecological significance and complexity of $\mathrm{N}$-source preference in plants. Annals of Botany 112 (6): 957-963. doi: 10.1093/aob/mct157

Finlay RD (2005). Action and interaction in the mycorrhizal hyphosphere: a re-evaluation of the role of mycorrhizal symbiosis in nutrient acquisition and plant ecology. In: "Nutrient acquisition by plants: an ecological perspective" (BassiriRad H ed). Springer-Verlag, Heidelberg, Germany, pp. 221-276. - doi: 10.1007/3-54027675-0_9

Finzi AC, Berthrong ST (2005). The uptake of amino acids by microbes and trees in three cold-temperature forests. Ecology 86: 33453353. - doi: 10.1890/04-1460

Gao JQ, Mo Y, Zhang XW, Gao JJ, Deng ZH, Xu XL (2014). Spatio-temporal variations alter the preference for nitrogen forms by three dominant plant species in an alpine wetlands. Plant and Soil 381: 271-278. - doi: 10.1007/s11104-014-2130-9 George E, Marschner H, Jakobsen I (1995). Role of arbuscular mycorrhizal fungi in uptake of phosphorus and nitrogen from the soil. Critical Reviews in Biotechnology 15: 257-270. - doi: 10.3109/07388559509147412

Harrison KA, Bol R, Bardgett RD (2007). Preferences for different nitrogen forms by coexisting plant species and soil microbes. Ecology 88 (4): 989-999. - doi: 10.1890/06-1018

Hodge A, Fitter AH (2010). Substantial nitrogen acquisition by arbuscular mycorrhizal fungi from organic material has implications for $\mathrm{N} \mathrm{cy-}$ cling. Proceedings of the National Academy of Sciences USA 107: 13754-13759. - doi: 10.1073/ pnas. 1005874107

Hooper DU, Vitousek PM (1997). The effects of plant composition and diversity on ecosystem processes. Science 277: 1302-1305. - doi: 10.1126/ science.277.5330.1302

Jones DL, Healey JR, Willett VB, Farrar JF, Hodge $A$ (2005). Dissolved organic nitrogen uptake by plants-an important $\mathrm{N}$ uptake pathway? Soil Biology and Biochemistry 37: 413-423. - doi: 10.1016/j.soilbio.2004.08.008

Kou L, Guo DL, Yang H, Gao WL, Li SG (2015). Growth, morphological traits and mycorrhizal colonization of fine roots respond differently to nitrogen addition in a slash pine plantation in subtropical China. Plant and Soil 391: 207-218. doi: 10.1007/s11104-015-2420-X

Kuzyakov Y, Xu XL (2013). Competition between roots and microorganisms for nitrogen: mechanisms and ecological relevance. New Phytologist 198 (3): 656-669. - doi: 10.1111/nph.12235

LeBauer DS, Treseder KK (2008). Nitrogen limitation of net primary productivity in terrestrial ecosystems is globally distributed. Ecology 89: 371-379. - doi: 10.1890/06-2057.1

Leduc SD, Rothstein DE (2010). Plant-available organic and mineral nitrogen shift in dominance with forest stand age. Ecology 91 (3): 708720. - doi: 10.1890/09-0140.1

Li HM, Tao GF, Xu L, Ni LJ, Jiang XN, Zhou CQ, Yang Y, Zhang CB (2011). Effects of plant functional group diversity on microbial biomass and nutrient retention in a constructed wetland. Journal of Plant Nutrition and Fertilizer 17 (6): 1365-1371. [online] URL: http://en.cnki.com.cn/ Article en/CJFDTOTAL-ZWYF201106011.htm Lipson D, Näsholm T (2001). The unexpected versatility of plants: organic nitrogen use and availability in terrestrial ecosystems. Oecologia 128: 305-316. - doi: 10.1007/s004420100693 Ma ZQ, Hartmann H, Wang HM, Li QK, Wang YD, Li SG (2014). Carbon dynamics and stability between native Masson pine and exotic slash pine plantations in subtropical China. European Journal of Forest Research 133: 307-321. - doi: 10.1007/s10342-013-0763-5

Marschner H, Dell B (1994). Nutrient uptake in mycorrhizal symbiosis. Plant and soil 159 (1): 89102. [online] URL: http://link.springer.com/arti cle/10.1007/BFoo000098

McKane RB, Johnson LC, Shaver GR, Nadelhoffer KJ, Rastetter EB, Fry B, Giblin AE, Kielland K, Kwiatkowski BL, Laundre JA, Murray G (2002). Resource-based niches provide a basis for plant species diversity and dominance in arctic tundra. Nature 415: 68-71. - doi: 10.1038/415068a Miransari M (2011). Arbuscular mycorrhizal fungi and nitrogen uptake. Archive of Microbiology 193 (2): 77-81. - doi: 10.1007/s00203-010-0657-6

Näsholm T, Kielland K, Ganeteg U (2009). Uptake of organic nitrogen by plants. New Phytologist 182 (1): 31-48. - doi: 10.1111/j.1469-8137.20 08.02751.x

Nordin A, Schmidt IK, Shaver GR (2004). Nitrogen uptake by arctic soil microbes and plants in relation to soil nitrogen supply. Ecology 85 (4): 955-962. - doi: 10.1890/03-0084

Nye $\mathrm{PH}$ (1981). Changes of $\mathrm{pH}$ across the rhizosphere induced by roots. Plant and Soil 61 (1-2): 7-26. - doi: 10.1007/BF02277359

Read DJ, Perez-Moreno J (2003). Mycorrhizas and nutrient cycling in ecosystems - a journey towards relevance? New Phytologist 157: 475492. - doi: 10.1046/j.1469-8137.2003.00704.x

Schmidt S, Mason M, Sangtiean T, Stewart GR (2003). Do cluster roots of Hakea actities (Proteaceae) acquire complex organic nitrogen? Plant and Soil 248 (1): 157-165. - doi: 10.1023/ A:1022352415728

Schmidt S, Stewart GR (1997). Waterlogging and fire impacts on nitrogen availability and utilization in a subtropical wet heathland (wallum). Plant, Cell and Environment 20: 1231-1241. - doi: 10.1046/j.1365-3040.1997.d01-20.x

SITCAS (1989). Management and development of red hilly area experimental study in Qianyanzhou. Scientific Investigation Team of Chinese Academy of Sciences for Southern Mountainous Areas - SITCAS, Management Office of Natural Resources, Ji'an Prefecture, Jiangxi Province, Chinese Science Press, Beijing, China, pp. 1-23.

Smith SE, Read DJ (2008). Mycorrhizal symbiosis ( $3^{\text {rd }}$ edn). Elsevier-Academic Press, London, UK, pp. 787.

Van Breemen N, Mulder J, Driscoll CT (1983). Acidification and alkalinization of soils. Plant and soil 75 (3): 283-308. - doi: 10.1007/BF02369 968

Veresoglou SD, Chen B, Rillig MC (2012). Arbuscular mycorrhiza and soil nitrogen cycling. Soil Biology and Biochemistry 46: 53-62. - doi: 10.101 6/j.soilbio.2011.11.018 
Wang SQ, Liu JY, Zhang C, Yi CX, Wu WX (2011). Effects of afforestation on soil carbon turnover in China's subtropical region. Geographic Science 21: 118-34. - doi: 10.1007/s11442-011-0833-x Warren CR (2006). Potential organic and inorganic $\mathrm{N}$ uptake by six Eucalyptus species. Functional Plant Biology 33 (7): 653-66o. - doi: 10.1071/FP06045

Warren CR, Adams PR (2007). Uptake of nitrate, ammonium and glycine by plants of Tasmanian wet eucalypt forests. Tree Physiology 27 (3): 413-419. - doi: 10.1093/treephys/27.3.413

Warren CR (2009a). Does nitrogen concentration affect relative uptake rates of nitrate, ammonium, and glycine? Plant Nutrition and
Soil Science 172: 224-229. - doi: 10.1002/jpln.20 0800251

Warren CR (2009b). Uptake of inorganic and amino acid nitrogen from soil by Eucalyptus regnans and Eucalyptus pauciflora seedlings. Tree Physiology 29 (3): 401-409. - doi: 10.1093/ treephys/tpno37

Warren CR (2014). Organic N molecules in the soil solution: what is known, what is unknown and the path forwards. Plant and Soil 375: 1-19. doi: 10.1007/s11104-013-1939-y

Wen XF, Yu GR, Sun XM, Li QK, Liu YF, Zhang LM, Ren CY, Fu YL, Li ZQ (2006). Soil moisture effect on the temperature dependence of ecosystem respiration in a subtropical Pinus plantation of southeastern China. Agricultural and Forest Meteorology 137 (3-4): 166-175. - doi: 10.1016/j.agrformet.2006.02.005

Xu XL, Bai JB, Ou YH (2011). Advances in studies on organic nitrogen uptake by terrestrial plants. Journal of Natural Resources 26 (4): 715 724. [online] URL: http://en.cnki.com.cn/Article en/CJFDTOTAL-ZRZX201104018.htm

Xu X, Ouyang H, Cao G, Pei Z, Zhou C (2004). Uptake of organic nitrogen by eight dominant plant species in Kobresia meadows. Nutrient Cycling in Agroecosystems 69 (1): 5-10. - doi: 10.1023/B:FRES.0000025288.48444.60 